\title{
A REFLECTION ON LITERARY CANON AND TRANSLATION: The case of Spain in the Late 1990s and early 2000s
}

Isabel Herrando Rodrigo

Universidad de Zaragoza

Until very recently I have thought that the word canon was just related to Art or to the "beauty" arena. Nonetheless, I started to reflect on this issue due to the comments launched in the Media about the Spanish; Premio Planeta. After handling different readings related to this previously mentioned issue, I began to question what canon is, or what it should be; who establishes that canon and how he or she does it, not only as far as literature is concerned but also as far as Media, humour, children literature -for instance the case of Harry Potter's films or Almodovar; a living canon in the year 2000 , despised in the 1980 s-. Have painters got to be dead to be a part of the Art canon being even dismissed when being alive? To be more specific, we should ask to ourselves direct questions such as: What about literature? Who establishes which written pieces should be excluded from the literature arena and which ones should be best sellers or referential landmarks? Who decides which works deserve the process of being translated into other languages?. Focusing now our attention on the writer we could foresee other questions on his or her behalf as regards canonicity: How can a writer be within a canon? Has he or she got to be dead, too modern, too shocking in order to enter the present canon?

I could continue launching questions and more questions but a few weeks ago I was shocked by something I categorized as a "phenomenon" and that suddenly made me realise that all this issue could be related just with an evolution of taste among other facts such as; a shift of taste; a shift of standard; an issue of status or prestige; a fact or real product of our literature system. As I have previously mentioned, if I were asked about canon in literature I would have thought about the classics. But, which classics?

The event I was making reference above was just an anecdote. At the beginning of September I was looking after a $1^{\circ}$ Bachillerato Maths exam in the school I teach. Unfortunately for them, this exams was very 'short', in other words, they finish too fast. It was 9.30 am and they could not 


\section{A REFLECTION ON LITERARY CANON AND TRANSLATION}

leave the room until $10.30 \mathrm{am}$. Therefore I told them to make the most of their spare time in order to revise for their next exam. In that moment most of the students took out from their back bags; El maestro de Esgrima from A. Pérez-Reverte.'I asked why they were reading that book and they answered that it was for the Spanish Language class. That was my shock that later turned into a reflection: A book that I have read for plcasure ten years ago is now a part of the literary canon of my seventeen-year-old students academic curriculum.

This exploratory reflection would try to be a theoretical approach to the question of canon and to its reality in the Spanish litcrature during the end of the XX century and beginning of XXI c. Thus as regards corpus, the issue of Anthologies and the figures of published books in Spain among the last ten years 1996-2006 have been studied.

It has been said that the Unite States of America contributed with Ronald Regan in 1980 to the concept of canon with his promotion of an aggressively traditionalist cultural discourse which apparently supported and enhanced his presidential legitimacy. From a powerful position; values, believes and feelings were transmitted. This situation of control enables a minority to manipulate a large population.

This situation, quoted as an example, helps to explain why so much energy is being spent on the issue of the role of literature and its interpretation in the construction of images and national symbols of identity. This is believed to have a political effect. Ericsson (1992) highlighted another feature that Thatcherism shared with the Regan leadership:

This high-minded, noble-sounding defence of the great tradition is understood formthe traditionalist standpoint as the curtailment of the new scholarship focusing on the political implications of race and gender and as the restoration of our literacy heritage to its rightful place as a 'positive' inspirational force in national life. (1992: 440)

At that time, in the $60 \mathrm{~s}$ and $80 \mathrm{~s}$ a cultural difference or 'ethnicity' was emerging in those previously mentioned countries. Outside the 'big countries' we could talk about what Lambert coined as "Literary Maps" and cultural maps (1991).

He points out that due to the difficult social and political situation; there is a mixture of languages, cultures and traditions. This ambiguity exists due to the non existence of borderlines. This extrapolated to our current life could be known as an internationalization of the society; it may be called as well globalization.

According to Pozuelo Yvancos (2000: 3) the issue of reading in Spain got a turning point with the esthetical review of the Spanish canon carried out by Harold Bloom; The Western Canon (1994). These two scholars highlight the importance of questions such as: What should be taught? How can we make literature alive in our societies? What is tradition? What is more, this issue leads to another fact which I observe with concern: Which is the role of "Human Science" in secondary education or at University? This is a very difficult question, moreover taking into account that we are living in an age in which ICT, television, cinema, etc take the dominant part as regards Spanish citizens. This 'alarm', made Spanish scholars think and rescarch about what other European colleagues had been doing along years: To try to establish an objective study of the Spanish literary corpora. I hereby attemp to approach this matter by means of regarding the concept of anthology. Later on, I will make reference to the Spanish publishing panorama in this last decade.

When I first thought about the word 'anthology', the first thing that came to my mind was "The Spanish Song Anthology". How does a producer create an anthology CD? What criteria does he or she follow? What criteria should I follow when I record a CD for my personal pleasure: historic, objective or my personal taste criteria?

1.- Pérez-Reverte, A., (1988) Santillana. Madrid 


\section{ISABEL HERRANDO RODRIGO}

When we gather or collect books or music samples for our personal enjoyment we do follow criteria. Even though everybody is different and is exposed to the same works or stimuli we do react in many different fashions. Every reading is different, and in any reading we conceive as ours the reading we have been through. Thus, our personal or domestic 'anthologies' are made according to our tastes, values, previous experiences, memories, etc.

Scholars who are in charge of elaborating literature anthologies, for instance, do gather corpora following some principles. When doing so, they may follow Even-Zohar (1999: 23-52) criteria which suggests a dynamic system structured by hierarchic couples such as centre-periphery, primary-secondary, canonical-non canonical. According to Garrido Gallardo (1988: 20) Fowler considered the question on genre, a decisive factor at the time of determine literary canon. This scholar considered that there are certain genres that at first sight are considered more canonical than others.

It can also be claimed that society also establishes a kind of literary 'musts', as the fashion term; works you must read in order to relate yourself in your public life, such as La sombra del viento or The DaVinci Code. In addition, in order to follow up the idea we are developing in this section, we should also say that from this perspective any reader has expectations or previous ideas about what she or he is going to read. Even, if what she or he is going to read is presented with the heading; Anthology. Does a heading predispose a reader?

Torodov (1988: 31-48) resembles the concept of genre as a layout or "way of presenting". Talking about the same fields, Lucia Re exposed that Anthology means the same as genre: "the poetry anthology is a literary genre in and of itself, for it constitutes a kind of creative writing, or rewriting, of literary tradition" (1992: 586) Getting to this point, we should be careful not to enter in the genre field.

Among others, Fowler and even Alfonso Reyes, highlight the importance of selecting pieces of literature in order to facilitate the historic study for future generations. Both of them give to Anthology a crucial function:

[...] de engendrar y aglutinar en su interior aquellos cambios literarios, que pretenden perpetuarse como norma estética y que confirman un nuevo canon literario porque en su interior se marcan hitos de las grandes controversias críticas, sea que las provoquen o que aparezcan como su consecuencia. (Reyes, 1948: 136)

To conclude this section, we have to talk about Enric Sullà (1998: 11-14) who highlights the important existing relation between canon and power, canon and institution. He thinks that if there is a process of selection in order to create an anthology, this process transforms this selection into a canon. We do infer from our birth, that the culture, in which we live, is the ordinary culture to have; the rule, the norm, the unmarked: the Western culture. However, we still believe that to create a canon is a source of discussion about what to teach, what values are the most representative to be transmitted or transferred. In all, this has been and it will be a crucial question that has gone along all the cultural institutions during History.

To continue this reflection, I would like to quote a study that was carried out a few months ago by "Departamento de Ciencias de la Documentación de la Universidad de Zaragoza" and "Universidad Complutense de Madrid" named Evaluación de la calidad de las revistas españolas de humanidades y ciencias sociales. This study suggests the possibility of existence of a kind of a 1990s reading canon. It has been suggested that the quality of work is measured according to the number of languages to which it has been translated.

Leaving these globalizating criteria, we do analyse here what the Spanish audience has read during these last ten years. This decade began with a kind of Sex, Drugs and Rock \& Roll hangover characterised by Ángel Mañas X generation: Historias del Kronen. 1994; together with the tide of writers which passed by; Octavio Paz, J. A. Goytisolo, Camilo 


\section{A REFLECTION ON LITERARY CANON AND TRANSLATION}

José Cela, Manuel Vázquez Montalbán, Terenci Moix, Dulce Chacón, Arthur Miller among others.

Few writers are still known from that time, maybe eclipsed by Mañas shadow with the exception of Juan Bonilla; Nadie conoce a Nadie. 1995. But 1997 is an age of extremes, Lucia Echeverría with her Amor; curiosidad, Prozac y dudas and her one year later Beatriz y los cuerpos celestes establishes a fashion of surprising or even scandalise the reader. However, Carmen Martín Gaite or Ana María Matute are, at that time a sample of traditional Hispanic writers. 1996 is also a year for essays: Moix’s Mujercísimas, Delibes'He dicho, Gala's El manuscrito carmesí.

Together with them, Martínez de Pisón (Carreteras Secundarias) and Pérez. Reverte, are writers who still bet for works of art with hardly no promotion but with a big success. During these first years of the decade and from outside our frontier, I would not like to neglect the importance of Irving Welsh Trainspotting, Jostein Gaarder's El mundo de Sofía or the very recent film success of Annie Prouls, Brokeback Mountain.

A lot of scholars claim that the literary market has also demands, and that 1997 onwards is an example of that. 1997 exemplifies the demand of Karlos Arguiñano recepees' books together with books based on ETA, Gal etc.

About 1998 religious, historic and spiritual books are on vogue. We can think of Coclho's El Alquimista, Goleman's La inteligencia emocional, atorised biographies such as; Ernesto Guevara from Paco Ignacio Taibo, etc.

Getting to the year 2000 detective novels are also demanded but if these last five years have been characterised by something, it has been by the best seller phenomenon. The benefits obsession, has made editorials bet; a secure bet. Titles which support the fantastic view of the readers have gathered thousand of purchases. We just have to think of titles such as: Harry Potter or The Lord of the Rings. But if we have to estimate a genre that would be a mixture of historic, sensationalist and fantastic novel such as Dan Brown's The Da Vinci Code.

More and more, journalists are demanding a piece of glory trough the publication of research projects such as Anna Politkovskaya's La Rusia de Putin or John Lee Anderson's La caída de Bagdag. We constantly live in the age of jubilees: 30 years from Franco's death such as; Franco top secret from Jose Lesta y Miguel Pedrero, Franco y sus generales from Luis Suárez, etc. We have also celebrated launchings from Julio Verne, Agatha Cristic or Andersen.

Eventually and in order to finish this reflection of the Spanish panorama in this last decade, allow me to talk about figures which may clarify what it has just been said. The Spanish INE claims that in 1996, 50.159 books were published, and in 2006: 53,155.

I hereby finish by making reference to table 1 from the Appendix which exemplifies the "best sellers" along these ten years. However, we have to bare in mind that it does not matter how many books have been sold 200 million, 281 ... while, according to Qué Leer (june 2006: 54), half of the Spanish population has never read a book. 


\section{APPENDIX 1}

Table 1.

\begin{tabular}{|c|c|c|}
\hline & FICTION & NON FICTION \\
\hline 1996 & $\begin{array}{l}\text { La piel del tambor } \\
\text { Arturo Pérez-Reverte }\end{array}$ & $\begin{array}{l}\text { Noticia de un secuestro } \\
\text { Gabriel García Márquez }\end{array}$ \\
\hline 1997 & $\begin{array}{l}\text { Las aventuras del capitán Alatriste } \\
\text { Arturo Pérez-Reverte }\end{array}$ & $\begin{array}{l}\text { La Reina } \\
\text { Pilar Urbano }\end{array}$ \\
\hline 1998 & $\begin{array}{l}\text { El dios de las pequeñas cosas } \\
\text { Arundhati Roy }\end{array}$ & $\begin{array}{l}\text { El bucle melancólico } \\
\text { Jon Juaristi }\end{array}$ \\
\hline 1999 & $\begin{array}{l}\text { Alexandros: El hijo del sueño } \\
\text { Valerio Manfredi }\end{array}$ & $\begin{array}{l}\text { Solas } \\
\text { Carmen Alborch }\end{array}$ \\
\hline 2000 & $\begin{array}{l}\text { La carta esférica } \\
\text { Arturo Pérez-Reverte }\end{array}$ & $\begin{array}{l}\text { La cruda y tierna realidad } \\
\text { José Luis de Vilallonga }\end{array}$ \\
\hline 2001 & $\begin{array}{l}\text { Soldados de Salamina } \\
\text { Javier Cercas }\end{array}$ & $\begin{array}{l}\text { ¿Quién se ha llevado mi queso? } \\
\text { Spencer Johnson }\end{array}$ \\
\hline 2002 & $\begin{array}{l}\text { Soldados de Salamina } \\
\text { Javier Cercas }\end{array}$ & $\begin{array}{l}\text { Vivir para contarla } \\
\text { Gabriel García Márquezz }\end{array}$ \\
\hline 2003 & $\begin{array}{l}\text { La sombra del Viento } \\
\text { Carlos Ruiz Zafón }\end{array}$ & $\begin{array}{l}\text { Diario de un Skin } \\
\text { Antonio Salas }\end{array}$ \\
\hline 2004 & $\begin{array}{l}\text { El código Da Vinci } \\
\text { Dan Brown }\end{array}$ & $\begin{array}{l}\text { La Buena suerte } \\
\text { Fernando Trias de Bes and Alex Rovira }\end{array}$ \\
\hline 2005 & $\begin{array}{l}\text { Ángeles y demonios } \\
\text { Dan Brown }\end{array}$ & $\begin{array}{l}\text { Una breve historia de casi todo } \\
\text { Hill Bryson }\end{array}$ \\
\hline
\end{tabular}

\section{WORKS CITED}

Bloom, Harold (1994) El Canon occidental. La escuela y los libros de todas las épocas. Anagrama. Barcelona.

Culler, Jonathan (1999) "El futuro de las humanidades". El canon literario. Enric Sullá (Ed.) Arcos Libros, pp 23-52. Madrid.

Even-Zohar, Itamar (1999) "Factores y dependencias en la cultura. Una revisión de la Teoría de los Polisistemas", Montserrat Iglesias Santos (Eds). Arco Libros pp. 23-52. Madrid.

Ericsson, Peter (1992) "The Question of the Canon: The Examples of Searle Kimball and Kerman" Textual Practice. VI (3): 439-451.

Fowler, Alastair (1982) Kinds of Literatura. An introduction to the theory of genres and modes. Claredon Press. Oxford.

Lambert, José (1991) "Literaturas, Translation and (De)Colonization". In Theresa Hyun and José Lambert (Eds), Translation and Modernization. (Prodeedings of the XIIth Congress of the International Comparative Literature Association). Tokyo: ICLA, 98-117. 


\section{A REFLECTION ON LITERARY CANON AND TRANSLATION}

Pérez-Reverte, Arturo (1988) El Maestro de Esgrima. Santillana. Madrid.

Pozuelo Yvancos, José María y Aradra Sánchez, Rosa María (2000) Teoría del canon y la literatura española. Cátedra. Madrid.

Re, Lucia (1992) "(De)Constructing the Canon: The Agnon of the Anthologies on the Scene of Modern Italy Poetry" Modern Languages Notes. VOL. 87, n3, pp. 585-602.

Reyes, Alfonso (1948) "Teoría de la Antología”, La experiencia literaria, Losada. Buenos Aires. 135-140.

Sullà, Enric (1998) El canon literario. Arco Libros. Madrid.

Todorov, Tzvetan (1988) "El origen de los géneros", Teorías de los géneros literarios. Miguel Ángel Garrido Gallardo (Ed), Arco Libros. pp. 31-48. Madrid.

Vera Méndez, Juan Domingo (2005) Revista de estudios literarios. Universidad Complutense de Madrid. http: //www.ucm.es/info/especulo/numero30/antcanon.html 